\title{
Pengaruh Orientasi Kewirausahaan Terhadap Kinerja Usaha Pada Industri UMKM Abon Ikan Di Kota Makassar The Effect of Entrepreneurship Orientation toward Business Performance In Fish Abon SME Industry In Makassar City
}

\author{
Ayu wulandary ${ }^{1}$, Burhanuddin ${ }^{2}$, Wahyu Budi Priatna ${ }^{2}$ \\ 1) Program Studi Magister Sains Agribisnis, Departemen Agribisnis, Fakultas Ekonomi \\ dan Manajemen, Institut Pertanian Bogor \\ 2) Departemen Agribisnis, Fakultas Ekonomi dan Manajemen, Institut Pertanian Bogor
}

\begin{abstract}
Business performance is one of the benchmarks of entrepreneurship orientation so that the concept of entrepreneurship orientation of the entrepreneur is important because it has impacts on business performance. The entrepreneurship orientation is shaped by the five dimensions of innovation: risk-taking, proactiveness, competitive aggressiveness, and autonomy. The objective of this study was to analyze the influence of entrepreneurship orientation on business performance of fish abon SME in Makassar. This research employed a Structural Equation Modeling-Partial Least Square (SEM-PLS) 3.0 tool for quantitative analysis. The results of this study indicated that the influence of entrepreneurship orientation had a positive and significant impact on business performance. It could be observed that $t$ statistic value was 3,302> 1.96 and p-value was $0.001<0.05$, it meant that any improvement to the business adopting entrepreneurship orientation would improve business performance at fish abon SME in Makassar City.
\end{abstract}

Keywords: Entrepreneurship Orientation, Business Performance, SME, Abon Fish, Partial Least Square (PLS)

\section{Pendahuluan}

Kinerja usaha merupakan salah satu tolak ukur dari perilaku kewirausahaan, sehingga adanya konsep perilaku kewirausahaan pada pelaku usaha merupakan hal yang penting yang akan berdampak pada kinerja usaha. Di Indonesia UMKM hampir sebagian besar menguasai sektor usaha, khususnya bidang pertanian, perikanan, dan peternakan. Kehadiran UMKM dapat menjadi pemicu masyarakat untuk selalu berfikir ke arah usaha yang bersifat kewrirausahaan. Menurut Partomo \& Soejoedono (2002) industri mikro dan kecil menyumbang pembangunan dengan berbagai jalan, menciptakan kesempatan kerja, dan menyediakan fleksibilitas kebutuhan serta inovasi dalam perekonomian.

Besarnya perkembangan UMKM di Indonesia diikuti oleh besanya potensi sumber daya yang dimiliki. Hal ini dapat dilihat dari luas laut dan jumlah pulau yang besar sehingga Indonesia memiliki potensi sumber daya kelautan yang besar. Sejalan

dengan itu, maka pembangunan sektor perikanan harus berorientasi pada peningkatan produktivitas, nilai tambah dan perluasan kesempatan usaha sektor perikanan (Tajerin et al 2010). Salah satu usaha yang banyak digeluti oleh sebagian masyarakat Indonesia adalah di bidang pangan. Salah satunya olahan industri prikanan, dimana pengolahan tersebut adalah pengolahan hasil tangkap. Ikan merupakan salah satu komoditas yang banyak di konsumsi 
masyarakat di Indonesia. Trend konsumsi ikan selama tahun 2011 sampai 2015 menunjukkan peningkatan sebesar 6.27 persen. Peningkatan konsumsi ikan selama 5 tahun terakhir adalah hasil dari berbagai upaya kampanye dan kegiatan tentang gemar ikan kepada masyarakat. Data ini berdasarkan perhitungan konsumsi ikan survey sosial ekonomi nasional (Susenas) BPS (2015).

Bahan baku ikan sebagaian besar digunakan oleh industri pengolahan pangan yang umumnya bersekala kecil, menengah dan besar. Pada pengolahan ikan tersebut biasanya mereka membuat nugget, sosis, bakso atau abon ikan. Salah satu produk olahan ikan yang banyak dikonsumsi oleh masyarakat Indonesia adalah abon ikan. Industri abon ikan merupakan salah satu usaha yang berkembang dalam skala industri rumahan, dimana industri abon ikan ini juga termasuk dalam sektor industri pengolahan makanan dan minuman. Industri abon ikan ini banyak diusahakan oleh pelaku usaha di Kota Makassar. Sulawesi Selatan merupakan salah satu wilayah yang memiliki potensi sumberdaya perikanan yang beraneka ragam khususnya perikanan laut. Dengan melihat potensi di wilayah tersebut para pelaku usaha memiliki potensi untuk mengolah dan menambahkan suatu nilai tambah dari bahan baku tersebut. Salah satu produk unggulan di Dinas Perindustrian Perdagangan Koperasi dan UMKM Kota Makassar adalah industri abon ikan. Ini adalah alasan saya mengapa saya tertarik untuk meneliti industri rumahan abon ikan sebagai sampel usaha para wirausaha di Kota Makassar.

Industri rumahan abon ikan yang dijalankan oleh wirausaha di Kota Makassar Provinsi Sulawesi selatan, kinerja usaha yang dijalankan oleh wirausaha di kota Makassar sebagian besar kurang mengalami kemajuan atau berjalan di tempat saja, dikarenakan produksi laut tidak kontinyu dan kurangnya dukungan IPTEK dalam pelaksanaan usaha, kurangnya promosi, sedikitnya modal dari pemerintah, kerjasama pemasaran belum optimal, skala usaha masih kecil, dan bersifat musiman (waktu produksi tergantung musim dan cuaca). Kondisi alam berupa musim tidak menentu mengakibatkan para nelayan tidak setiap hari menangkap ikan ke laut sehingga ketersedian bahan baku tidak terjamin selalu ada. Sehingga harga abon ikan yang dipasarkan terjadi fluktuasi.

Oleh sebab itu, perlu diketahui penyebabnya mengapa kinerja usaha yang dijalankan oleh pelaku wirausaha kurang mengalami kemajuan. Berdasarkan hal tersebut, salah satu faktor mengapa kinerja pelaku wirausaha kurang mengalami kemajuan adalah salah satunya faktor dalam orinetasi wirausaha. Ketika kinerja usaha tersebut buruk dapat dilakukan perbaikan dalam menjalankan usaha, sebaliknya apabila kinerja usaha tersebut baik, dapat dilakukan peningkatan dalam menjalankan usaha. Oleh karena itu penelitian ini dapat mengkaji dengan melihat: (1) Bagaimana pengaruh orientasi kewirausahaan terhadap kinerja usaha UMKM abon ikan di Kota Makassar. Adapun tujuan dari penelitian ini adalah: (1) Menganalisis pengaruh orientasi kewirausahaan dapat meningkatkan kinerja usaha abon ikan di Kota Makassar.

\section{Metode}

Penelitian ini akan dilaksanakan di Kota Makassar. Pemilihan lokasi penelitian dilakukan secara sengaja (purposive) dengan pertimbangan bahwa di Kota Makassar merupakan salah satu sentra industri rumahan abon ikan. Pengumpulan data dilakukan selama 2 bulan dari bulan April sampai dengan Mei 2017.

Jenis dan data yang akan digunakan pada penelitian ini adalah data primer dan data sekunder. Data primer ini diperoleh melalui wawancara secara langsung dengan pelaku usaha abon ikan di kota Makassar dengan menggunakan dengan pertanyaan terstruktur dalam sebuah kuesioner. Data sekunder akan dikumpulkan dari Badan Pusat Statistik (BPS), Dinas Koperasi dan UMKM Kota Makassar, Dinas Perikanan dan Kelautan Kota Makassar. Berdasarkan informasi awal yang di dapatkan di Dinas Koperasi dan UMKM Makassar bahwa usaha abon ikan sebanyak 43 usaha abon ikan yang ada di kota makasar. Hal ini dilakukan dengan menggunakan teknik sensus dalam pengambilan sampel. Maka dari itu saya mengambil semua sampel yang ada di kota makassar. Data yang diperoleh dari penelitian ini adalah data kualitatif 
dan kuantitatif. Data kualitatif diperoleh melalui wawancara dan observasi selama penelitian. Sedangkan data kuantitatif diperoleh berupa data pelaku usaha pembuatan abon ikan, data profit dan nilai penjualan serta data penilaian orientasi kewirausahaan yang dimiliki masing-masing pelaku usaha pembuatan abon ikan. Analisis data dilakukan secara deskriptif dan kuantitatif.

Tabel 1 Variabel Laten dan Variabel Manifest/Indikator

\begin{tabular}{llc}
\hline Variabel Laten & Variabel Manifest & Rujukan \\
\hline Faktor Organisasi & Skala Usaha (Vm11) & Lumpkin dan Dess \\
& Struktur Usaha (Vm12) & $\begin{array}{c}\text { (1996), Zhou dan } \\
\text { Shalley (2003) }\end{array}$ \\
& Sumberdaya (Vm13) & \\
\hline Kepemimpinan Usaha (Vm14) & Milovanovic dan \\
& Hostility (Vm21) & Wittine (2014), Zahra \\
& Peluang Uravis (2000), \\
& Karakteristik Usaha (Vm23) & Lumpkin dan Dess \\
& Peran Pemerintah (Vm24) & \\
& Keinovatifan (X11) & \\
\hline OrientasiKewirausahaan Lingkungan & Proaktif (X12) & Lumpkin dan Dess \\
& Berani Mengmbil Risiko (X13) & (1996), \\
& Agresivitas Kompetitif (X14) & \\
& Otonomi (X15) & Riyanti (2003), \\
& Pertumbuhan Penjualan (Y11) & Puspitasari (2013) \\
\hline Kinerja Usaha & Keunggulan Bersaing (Y12) & \\
& Kepuasan Pelanggan (Y13) & \\
\hline
\end{tabular}

\section{HASIL DAN PEMBAHASAN}

\section{Pengaruh antara Orientasi Kewirausahaan dan Kinerja Usaha}

Penilaian model outer dilakukan dengan membandingkan loading factor. Nilai loading factor merupakan ukuran reflektif individual yang memiliki standar 0.7 (Ghozali 2008). Akan tetapi dalam penelitian ini diambil standar pengukuran 0.5 sudah dianggap cukup (Chin 1996). Berdasarkan model ini terdapat satu indikator yang memiliki nilai loading factor $(\lambda)$ dibawah standar 0.5 yaitu variabel VM11(Karakteristik Usaha), VM14 (Peran Pemerintah), VM23 (Otonomi), VM24 (Risk Taking), X13 (Skala Usaha), X15 (Kepemimpinan Usaha). Artinya tidak semua indikator dalam penelitian ini valid untuk menjelaskan variabel laten yang dipergunakan. Maka dari itu perlu validasi ulang untuk mendapatkan model akhir yang terbaik. Tahap selanjutnya yaitu dengan mengeluarkan nilai loading factor yang dibawah 0.5 tersebut, kemudian melakukan proses alogritma PLS-SEM model yang telah diperbaiki memberikan hasil yang valid. Berdasarkan hasil penelitian, maka loading factor harus dibawah 0.5. 


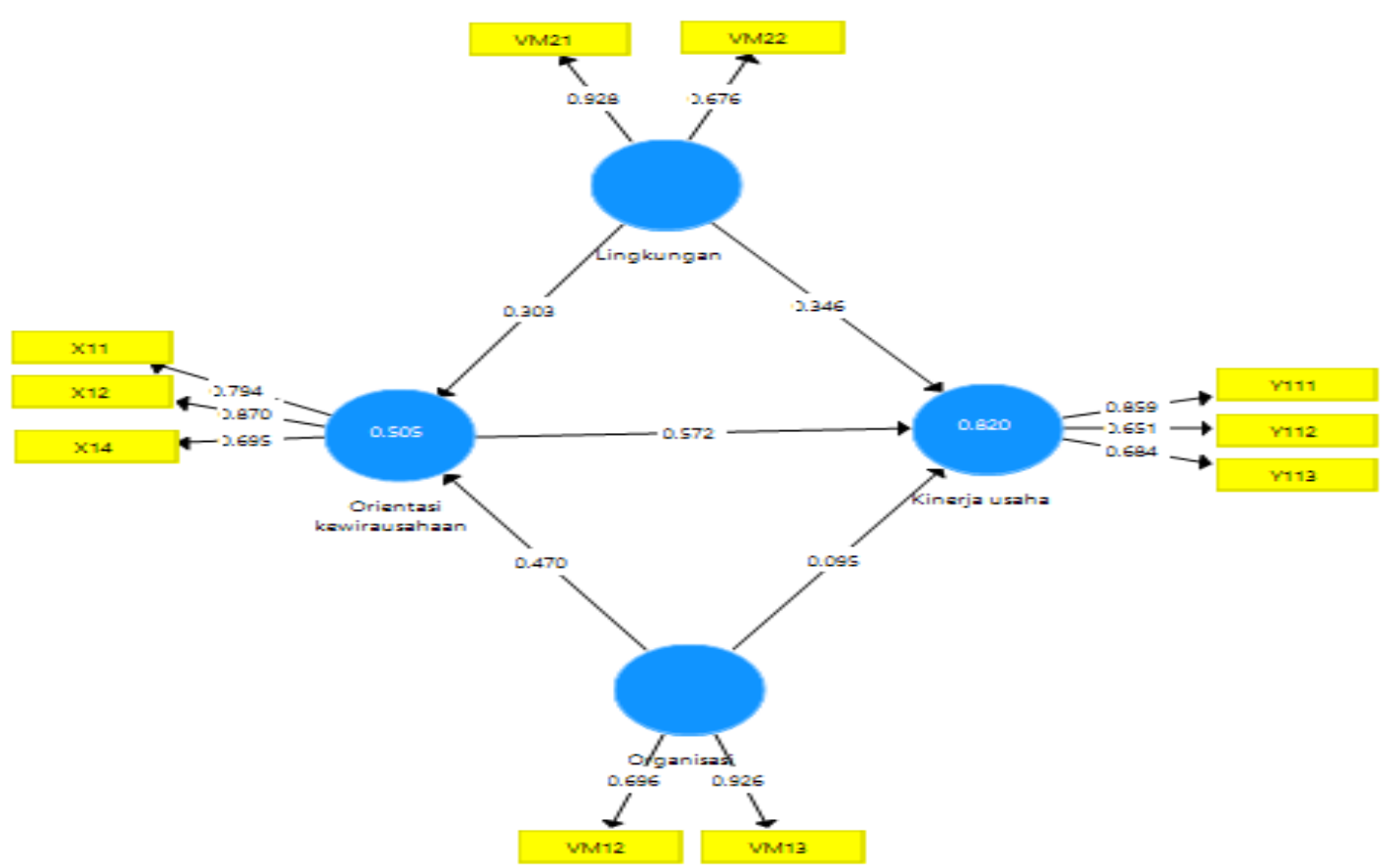

Gambar 1 Diagram path model resipikasi akhir dengan loading factor

Enam indikator yang ditolak pada hasil model awal PLS telah dikeluarkan sehingga persyaratan pertama pada model telah terpenuhi, kemudian dilakukan proses ulang tanpa indikator yang sudah dikeluarkan untuk memperoleh model yang terbaik. Berdasarkan hasil output PLS pada gambar 1 model akhir, maka diperoleh indikator yang memiliki nilai loading factor di atas 0.5 .

Tahap kedua yaitu evaluasi penilaian model struktural untuk melihat hubungan antar variabel laten dengan indikatornya. Hasil yang diperoleh dapat dilihat dari estimasi koefisien jalur serta tingkat signifikan. Dalam penelitian ini, model struktural yang diperoleh menjelaskan pengaruh orientasi kewirausahaan terhadap kinerja usaha.

Tabel 2 Evaluasi terhadap koefisien model struktural

\begin{tabular}{|c|c|c|c|c|}
\hline & Koefisien & T hitung & $\begin{array}{c}\mathrm{P} \\
\text { Values }\end{array}$ & Keterangan \\
\hline Lingkungan -> Kinerja usaha & 0.394 & 2.078 & 0.038 & Signifikan \\
\hline Lingkungan -> Orientasi kewirausahaan & 0.218 & 1.416 & 0.157 & $\begin{array}{c}\text { Tidak } \\
\text { signifikan }\end{array}$ \\
\hline Organisasi -> Kinerja usaha & 0.095 & 0.408 & 0.684 & $\begin{array}{l}\text { Tidak } \\
\text { signifikan }\end{array}$ \\
\hline Organisasi -> Orientasi kewirausahaan & 0.531 & 1.741 & 0.082 & $\begin{array}{c}\text { Tidak } \\
\text { signifikan }\end{array}$ \\
\hline $\begin{array}{l}\text { Orientasi kewirausahaan -> Kinerja } \\
\text { usaha }\end{array}$ & 0.618 & 3.302 & 0.001 & Signifikan \\
\hline
\end{tabular}

Keterangan : P-value $<0.05=$ Signifikan

Hasil pengujian hipotesa pada hasil bootstrapping pada koefesien path dan p-values menunjukkan bahwa faktor orientasi kewirausahaan secara langsung berpengaruh positif dan signifikan terhadap kinerja usaha pada taraf nyata 0.05 dengan nilai $\mathrm{p}$-value $<0.05$. Hal ini menunjukkan bahwa dengan menerapkan dimensi orientasi kewirausahaan terhadap usaha bahwa akan meningkatkan hasil kinerja usaha pada pelaku olahan abon ikan di Kota Makassar dengan dipengaruhi secara langsung oleh faktor lingkungan yang ada di sekitar pelaku usaha 
abon ikan. dengan demikian dapat disimpulkan bahwa hipotesis 2 dan 4 dapat diterima, sedangkan hipotesis 1,3 dan 5 tidak dapat diterima karena menunjukkan secara langsung berpengaruh positif dan berbeda nyata pada taraf nyata 0.05 .

Pada Gambar 1 kecocokkan model berkategori baik dimana nilai loading factor telah sesuai dengan standar pengujian, artinya model telah baik dalam menggambarkan data dan kondisi yang sebenarnya sehingga dapat disesuaikan dengan teori yang melandasinya. Berdasarkan Gambar 2 selanjutnya dilihat nilai t-statistik jika nilainya lebih dari 1.96 artinya model sudah fit. Berdasarkan hasil dari bostrapping PLS ini diperoleh nilai t-hitung lebih besar dari 1.96. Model hubungan kausal antara faktor-faktor yang berpengaruh terhadap orientasi kewirausahaan dan kinerja usaha pelaku usaha abon ikan menjelaskan pengaruh antara variabel laten yang satu terhadap variabel laten lainnya adalah positif. Validitas nilai t-hitung pada Gambar 2 juga menunjukkan bahwa variabel pada model mampu mengukur apa yang seharusnya diukur atau model mampu menjelaskan hubungan-hubugan antar variabel.

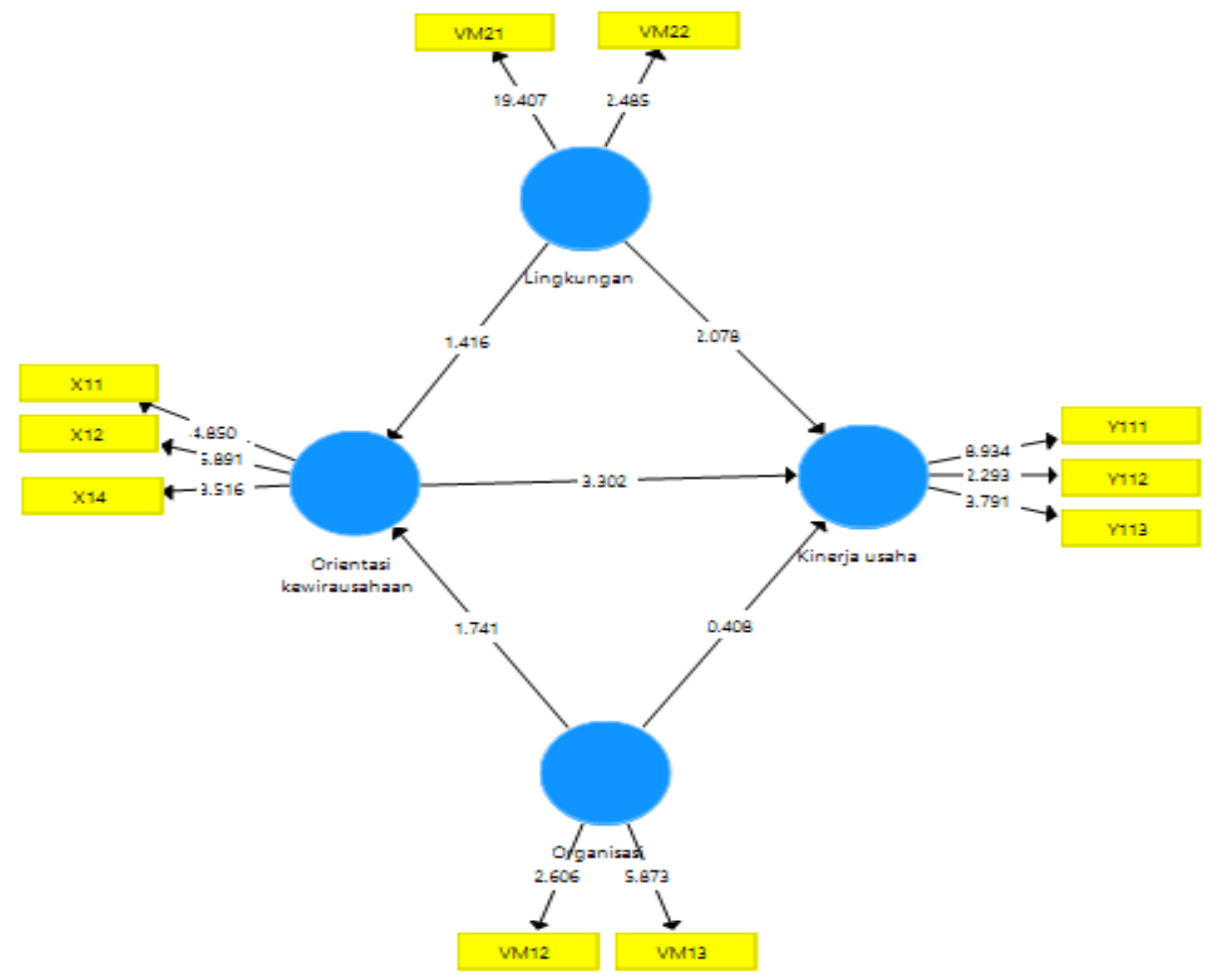

Gambar 2 model dengan nilai uji-t

\section{Pengaruh antara Orientasi Kewirausahaan dan Kinerja Usaha}

\section{Orientasi Kewirausahaan}

Variabel orientasi kewirausahaan berpengaruh positif dan signifikan dengan koefesien sebesar 0.618 yang artinya setiap peingkatan satu persen variabel faktor orientasi kewirausahaan maka akan meningkatkan kinerja usaha pelaku usaha abon ikan sebesar 61.8 persen, nilai pvalues sebesar 0.001 dimana sesuai dengan standar yaitu lebih kecil dari 0.05 dan t-statistic sebesar 3.302 dimana lebih besar dari t-table (1.96) yang berarti variabel orientasi kewirausahaan berpengaruh langsung terhadap kinerja usaha.

Variabel orientasi kewirausahaan direfleksikan tiga indikator yaitu keinofativan, proaktif, dan agresivitas kompetitif. Loading factor Terbesar ditunjukan oleh indikator proaktif (X12) dengan nilai 0.870. Berdasarkan dilapangan pelaku usaha mampu mencari kesempatan atau peluang usaha untuk berkompetisi dan cepat tanggap terhadap perubahan lingkungan di masa mendatang. Misalnya dalam hal ketersediaan bahan baku serta pemasaran produk. Oleh karena itu, dengan adanya perspektif tersebut pelaku usaha yang proaktif dapat memanfaatkan

Pengaruh Orientasi Kewirausahaan Terhadap Kinerja Usaha Pada Industri UMKM Abon Ikan (Ayu) 
peluang yang muncul (Keh et a. 2007). Perusahaan dengan pelaku usaha yang proaktif dapat memperoleh keuntungan dan membidik target segmen pasar sehingga dapat mengungguli pesaing (Lumpkin dan Dess 2001). Oleh karena itu, proaktif diharapkan akan berperan penting dalam mempertahankan keunggulan kinerja perusahaan (Lumpkin dan Dess 2001). Variabel kinerja usaha yang dibentuk oleh variabel orientasi kewirausahaan menunjukan bahwa adanya pengaruh langsung. Variabel orientasi kewirausahaan memiliki nilai $\mathrm{R}^{2}$ sebesar 0.495 persen. Sehingga hal ini menujukan bahwa orientasi kewirausahaan sangat berperan penting terhadap hasil kinerja perusahaan. Hal ini sama dengan penelitian yang diungkapkan oleh Rauch (2009) menyatakan bahwa bisnis yang mengadopsi orientasi kewirausahaan memiliki kinerja yang lebih baik dibandingkan dengan bisnis yang tidak mengadopsi orientasi kewirausahaan. Banyak studi yang mengenai orientasi kewirausahaan dengan kinerja usaha yang telah dikaitkan dan memiliki hal positif (Covin dan Slevin 1991). Maka hasil penelitian ini sesuai dengan hasil studi literatur. Akan tetapi, di sisi lain terdapat pula peelitian yang mengungkapkan bahwa orientasi kewirausahaan tidak memberikan hasil positif terhadap kinerja usaha yang merupakan penelitian dari Naldi (2007). Sehingga orientasi kewirausahaan memiliki dampak langsung dan tidak langsung untuk mencapai kinerja usaha yang maksimal tergantung pada lingkungan yang berbeda.

Pelaku usaha abon ikan di Kota makassar akan mengalami peningkatan kinerja usahanya, apabila pelaku usaha abon ikan tersebut menerapkan atau mengadopsi orientasi kewirausahaan dalam menjalankan usahanya. Penerapan orientasi kewirausahaan tersebut dapat mengatasi permasalahan laba tidak menetu dan kecenderungan kinerja semakin menurun atau tidak stabil yang dialami oleh pelaku usaha abon ikan di Kota Makassar. Maka dari itu dapat disimpulkan bahwa penerapan orientasi kewirausahaan adalah salah satu solusi untuk meningatkan kinerja usaha. Kinerja usaha pada pelaku usaha olahan abon ikan dijelaskan oleh pertumbuhan penjualan, keunggulan bersaing, dan kepuasan pelanggan. Pada pertumbuhan penjualan (Y11) memberikan kontribusi terbesar pada kinerja usaha dengan loading factor sebesar 0.859. Meskipun peningkatan terhadap pertumbuhan penjualan tidak terjadi 100 persen, namun pelaku usaha abon ikan telah dapat memenuhi kebutuhan sehari-hari, mengalokasikan ke modal selanjutnya seta dapat mengurangi beban hutang yang ada. Peningkatan pertumbuhan penjualan dapat terjadi apabila produksi terus ditingkatkan agar dapat memenuhi permintaan konsumen. Oleh karena itu dibutuhkan dukungan dari pemerintah dalam penyediaan modal serta sarana dan prasarana yang dapat menunjang keberlangsungan usaha. Kepuasan pelanggan (Y13) juga menyumbang loading factor yang cukup besar yaitu 0.684. Persepsi pelaku usaha abon ikan terhadap kepuasan pelanggan menunjukan kecenderungan meningkat. Ini dapat terjadi karena para konsumen selalu berulang untuk membeli abon ikan yang ditawarkan, sehingga minat para konsumen terhadap abon ikan meningkat. Sedangkan pada indikator keunggulan bersaing (Y12) memiliki nilai loading factor terkecil yaitu sebesar 0.651 dari hasil penelitian bahwa sementara indikator keunggulan bersaing dianggap masih rendah dalam menjelaskan kinerja usaha karena mayoritas pelaku usaha abon ikan masih mengalami peningkatan produksi yang tidak continue atau pada waktu-waktu tertentu hasil produksi dapat turun dikarenakan bahan baku yang sedikit terbatas didapatkan. Misalnya pada saat memasuki musim hujan dimana ombak kencang sehingga para nelayan tidak mampu untuk mencari ikan. Dengan terbatasnya bahan baku yaitu ikan, maka menimbulkan adanya peningkatan harga jual bahan baku. Sehingga bahan baku yang diperoleh terbatas pula dan proses produksi terhambat. Hal ini mencerminkan bahwa adanya pengurangan terhadap peningkatan kinerja usaha abon ikan.

\section{Simpulan dan Saran}

\section{Simpulan}

1. Indikator faktor organisasi yang membentuk orientasi kewirausahaan menunjukkan sebaran yang paling tinggi yaitu indikator kepemimpinan usaha dan sedangkan pada faktor lingkungan tidak menunjukkan adanya indikator yang dominan.

JoFSA Vol. 1, No. 2, Oktober $2017:$ 71-77 
2. Variabel dimensi orientasi kewirausahaan berpengaruh positif dan signifikan terhadap peningkatan kinerja usaha yang terdiri dari keinovatifan, proaktif dan agresivitas kompetitif dengan melihat nilai t-hitung sebesar 3.302 dan nilai p-values sebesar 0.001

\section{Saran}

Berdasarkan kesimpulan dirumuskan beberapa saran baik untuk pengembangan kinerja usaha pelaku usaha abon ikan maupun untuk penelitian selanjutnya yang relavan dengan topik penelitian. Adapun saran yang dapat disampaikan adalah sebagai berikut:

1. Pemerintah bekerjasama dengan UMKM abon ikan dapat memberikan pelatihan kewirausahaan yang akan bermanfaat untuk penerapan orientasi kewirausahaan dalam menjalankan usahanya

2. Perlu adanya penelitian lanjutan mengenai pengaruh faktor-faktor lain selain orientasi kewirausahaan yang berpengaruh terhadap kinerja usaha olahan abon ikan. Hal ini disarankan berdasarkan hasil penelitian, terdapat faktor lain selain orientasi kewirausahaan yang berpengaruh terhadap pembentukan kinerja usaha olahan abon ikan. Selain itu pembangunan kuesioner yang lebih terstandar sangat diperlukan untuk dapat menganalisis pengaruh orientasi kewirausahaan terhadap kinerja usaha dan kompetensi kewirausahaan dengan lebih baik.

\section{Daftar Pustaka}

Covin JG, Slevin DP. 1991. A conceptual model of entrepreneurship as firm behavior. Entrepreneurship: Theory and Practice. 16(1): 7-24.

Ghozali I, Latan H. 2014. Partial Least Square. Konsep, Teknik dan Aplikasi Menggunakan Program SmartPLS 3.0. Semarang [ID]. Universitas Diponegoro.

Lumpkin GT, Dess GG. 1996. Clarifying the entrepreneurial orientation construct and linking it toperformance. Academy of Management Review. 21: 13-172.

Lumpkin GT, Dess GG. 2001. Linking two dimensions of entrepreneurial orientation to firm performance: The moderating role of environment and industry life cycle. Journal of BusinessVenturing. 16: 429-451.

Milovanovic, Wittine. 2014. Analysis of external environment's moderating role on the entrepreneurial orientation and business performance relationship among Italian small enterprises. International Journal of Trade, Economics and Finance. 5(3).

Rauch A, Johan Wiklund, GT Lumpkin. 2009. Entrepreneurial orientation and business performance: An assessment of past research and suggestions for the future. Entrepreneurship Theory and Practice. 761-787.

Riyanti BP. 2003. Kewirausahaan Dari Sudut Pandang Psikologi Kepribadian. Jakarta. PT. Grasindo..

Zahra S, Garvis D. 2000. International corporate entrepreneurship and firm performance: The moderating effect of international environmental hostility.Journal of Business Venturing. 15: 469-492. 